Af Helle Guldberg, heg@kea.dk,

Biblioteksleder og leder af KEA Studieliv

\title{
Studiekompetence - studiestøttende aktiviteter
}

\author{
Biblioteket som frontløber i udvikling af studie- \\ kompetence til fastholdelse og understøttelse af \\ den enkelte studerende.
}

På biblioteket på Københavns Erhvervsakademi (KEA) er vi i gang med at implementere vort nyudviklede studiekompetencekoncept på alle vore uddannelser. Et koncept udviklet i biblioteksregi, der med progression i forhold til kvalifikationsrammen understøtter den enkelte studerende gennem hele studieforløbet med fokus på studentercentreret læring, fastholdelse, gennemførelse, den studerendes studieudbytte i centrum samt behovene på fremtidens arbejdsmarked.

\section{Baggrund}

Udgangspunktet for udviklingen af projekt Studiekompetence - studiestøttende aktiviteter var ønsket om at gøre en aktiv forskel og bruge den faglige viden, vi som biblioteksenhed rummer. Både i forhold til aktivt at understøtte og udvikle overgangen fra elev til studerende - så vore studerende er klædt bedre på til at gennemføre deres studie, og at sikre flere og fagligt stærkere dimittender, samt at vore dimittender har viden og værktøjer til at navigere på fremtidens komplekse og globale arbejdsmarked.

Rent konkret arbejder vi med at give vore studerende værktøjer og teknikker til for eksempel at kunne overskue større mængder af viden, kunne forstå akademisk sprogbrug, strukturere tiden, øge læsehastigheden, tage notater, anvende ny viden og trends samt problemløsning. Kort sagt alle de faktorer, der vurderes som essentielle i forhold til studieteknik og videnskompetence - både under studiet, men også med henblik på at kunne hjælpe den studerende på den fremtidige arbejdsplads.

\section{Den svære overgang}

Som studerende møder man nye måder at gøre tingene på. Man går fra at være elev til at være studerende, og er ikke længere i de trygge rammer, som gymnasier/erhvervsskoler har været for langt de fleste.

For andre, der fx søger via kvote 2, er overgangen endnu større, da det ofte er længe siden, de sidst har siddet på skolebænken. Overgangen er ikke let, og de studerende møder mange udfordringer i forløbet, hvilket medfører, at alt for mange giver op og dropper ud. Undersøgelser fra bl.a. Dansk Evalueringsinstitut (EVA) fremhæver to problemstillinger i forhold til fastholdelse og gennemførelse: For det første har en voldsom vækst i optaget af studerende medført, at der er meget stor forskel på de faglige forudsætninger blandt de studerende. Mange af de nye studerende mangler simpelthen de nødvendige studie- og videnskompetencer til at kunne indgå på en videregående uddannelse. For det andet bruger de fleste studerende ikke nok tid på deres studier, herunder på forberedelsen til undervisningen. Hvordan arbejdsindsatsen og stu- dieintensiteten øges, er derfor en af uddannelsesverdenens største udfordringer.

\section{Mangler studieteknisk viden}

En ny analyse fra EVA viser endvidere, at omkring halvdelen af nye studerende ikke deltager i undervisning $i$ studieteknik. Der findes videregående uddannelsesinstitutioner, som har studietekniske tilbud til de studerende. Trods behovet, deltager kun få studerende i de - typisk frivillige - tilbud, og desværre deltager sjældent de studerende, som har det største behov. Risikoen er, at den studerende mister modet, kommer bagud og til sidst dropper ud eller slæber sig gennem uddannelsen. Konsekvensen er et stort frafald. Det er uheldigt for både den studerende, samfundet, erhvervslivet og uddannelsesinstitutionen.

\section{Konceptet}

Vort mål var derfor at udvikle et koncept, der adresserede netop denne udfordring. Et koncept, der er skalerbart, integreret i undervisningen, fulgte kvalifikationsrammen og havde en progression, der understøttede den enkelte studerende under hele studiet - samt havde et digitalt fundament. Udviklingsfasen startede i 2017 og har været baseret på iterative processen og co-creation med både undervisere og studerende med et fast blik rettet mod vigtigheden af kontekst, kontekst og kontekst. 


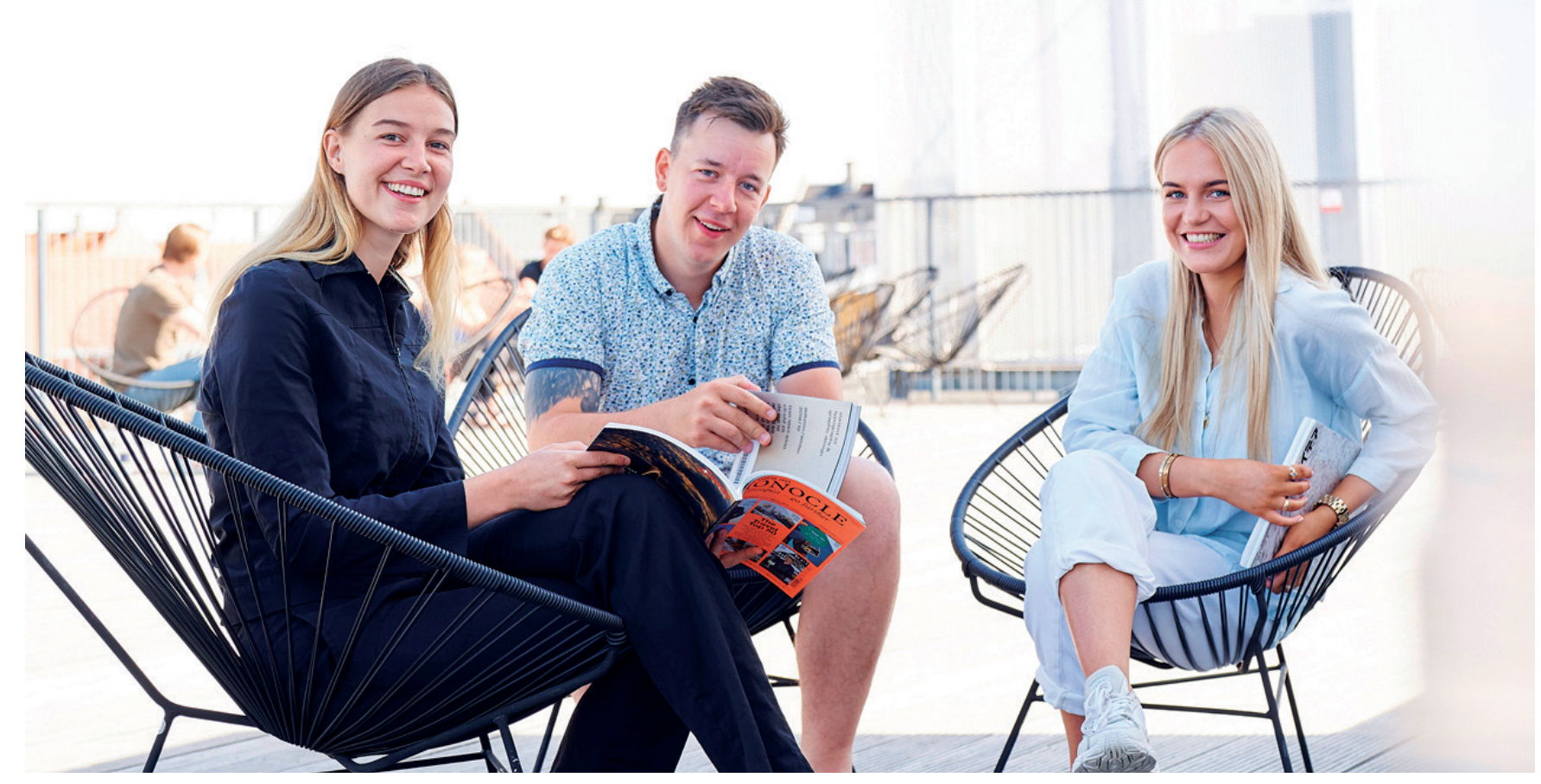

De studerende på KEA får kontinuerligt opkvalificeret deres studietekniske kompetencer

Vi gennemførte i 2018-2019 et pilotprojekt på vore tekniske uddannelser, hvor konceptet blev afprøvet, evalueret og tilpasset ønsker og behov. Vi er nu i implementeringsfasen, der løber frem til 2024, hvor konceptet vil være implementeret på alle uddannelser og næsten al undervisning i konceptets moduler vil være overgået til de fagfaglige undervisere.

Undervisningen er opdelt i moduler og til hvert modul hører: Læringsmål, undervisningsbeskrivelse, videoer, øvelser og quiz. Alle moduler ligger på portalen KEA Studieviden, så moduler, viden og værtøjer er tilgængelige, når og hvor som helst for både undervisere og studerende. Derudover har vi udviklet app'en 5 Korte, med fem punktnedslag indenfor: Kilder, Noter, Studielæsning, Planlægning og Research.

App'en er tilgængelig i både Google Play og App Store. Indholdet opdateres og udvikles kontinuerligt i samarbejde med undervisere og studerende, så det fremstår vedkommende og kontekstnært.

\section{Virker det?}

Hvordan måler vi så, om konceptet har den ønskede effekt? Ja, det er jo det, der er vanskeligt, for konceptet er et ud af flere tiltag, som KEA sat i søen for at sikre bedre fastholdelse og gennemførelse. Men med tiden skulle vi gerne kunne se flere fagligt stærke dimittender, bedre referencelister, mere kvalificeret videnssøgning - og en generel styrkelse af de områder, som vi adresserer med de enkelte moduler.

\begin{tabular}{|c|c|}
\hline 1. SEMESTER & \\
\hline TITEL & VARIGHED \\
\hline $\begin{array}{l}\text { VIDENKOMPETENCE } 1 \\
\text { Boost din researchproces }\end{array}$ & $45 \mathrm{~min}$ \\
\hline $\begin{array}{l}\text { KILDEKRITIK } \\
\text { Vælg de bedste kilder til dit formál }\end{array}$ & $45 \mathrm{~min}$ \\
\hline $\begin{array}{l}\text { STUDIETEKNIK } \\
\text { Sădan studerer du efffektivt }\end{array}$ & $90 \mathrm{~min}$ \\
\hline $\begin{array}{l}\text { STUDIEGRUPPEDANNELSE (i samarbejde med studievejleder) } \\
\text { Et samarbejdsmodul }\end{array}$ & $90 \mathrm{~min}$ \\
\hline
\end{tabular}

Moduloversigt 1.semester,

modulerne løber frem til endt uddannelse

\begin{tabular}{|c|c|}
\hline 2. SEMESTER & \\
\hline TITEL. & VARIGHED \\
\hline $\begin{array}{l}\text { VIDENKOMPETENCE } 2 \\
\text { Research i forbindelse med projektarbejde }\end{array}$ & $90 \mathrm{~min}$ \\
\hline $\begin{array}{l}\text { SKRIFTLIG FORMIDLING } \\
\text { Formidling og form }\end{array}$ & 90 min \\
\hline $\begin{array}{l}\text { REFERENCEHÅNDTERING } \\
\text { Citér dine kilder korrekt }\end{array}$ & $45 \mathrm{~min}$ \\
\hline $\begin{array}{l}\text { TEKNOLOGIFORSTÂELSE } \\
\text { Effektiv studieteknik i et digitalt miljø }\end{array}$ & $45 \mathrm{~min}$ \\
\hline FRIVILIIGE MODULER & \\
\hline $\begin{array}{l}\text { EKSAMENS- OG PRESENTATIONSTEKNIK } \\
\text { Fä styr på din fremlæggelse }\end{array}$ & $45 \mathrm{~min}$ \\
\hline $\begin{array}{l}\text { EKSAMENSANGST } \\
\text { Gør eksamen til en god oplevelse }\end{array}$ & $45 \mathrm{~min}$ \\
\hline
\end{tabular}

\section{Referencer \\ 1. Se f.eks. "Forskere og undervisere: Flere studerende er uegnede til universitetet” i Magisterbladet tilgået på https://www.magisterbladet.dk/magisterbladet/2017/072017/072017_p8 d. 30/5-2018 \\ 2. Se f.eks. "Studerende med størst behov deltager mindst i undervisningen i studieteknik" fra EVA, tilgået på https://www.eva.dk/videregaaende-uddannelse/studerende-stoerst-behov-deltager-mindst-undervisning- studieteknik-0 d. 30/5-2018}

